\title{
Diagnóstico, prevención y tratamiento de la osteonecrosis de los maxilares por bisfosfonatos. Recomendaciones de la Sociedad Española de Cirugía Oral y Maxilofacial (SECOM)*
}

\author{
Diagnosis, prevention, and treatment of bisphosphonate-associated \\ osteonecrosis of the jaw. Recommendations of the Spanish Society of Oral and \\ Maxillofacial Surgery (SECOM)
}

\author{
L.M. Junquera, R. Martín-Granizo
}

\begin{abstract}
Resumen: Los bisfosfonatos son análogos estables de los pirofosfatos inorgánicos que han demostrado su eficacia para el tratamiento de diversas patologías, como las lesiones osteolíticas asociadas a metástasis óseas o al mieloma múltiple, la hipercalcemia maligna, la enfermedad de Paget y la osteoporosis. En la actualidad se podría hablar, al menos académicamente, de dos entidades con diferentes grados de información científica: las osteonecrosis en relación con la administración intravenosa de estos medicamentos y las osteonecrosis en relación con la administración oral de los mismos. Para el primer grupo las estrategias de prevención y tratamiento empiezan a estar consolidadas, mientras que para el segundo se precisará de una mayor documentación científica para alcanzar este objetivo. Facilitar el diagnóstico clínico y complementario de las osteonecrosis por bisfosfonatos por parte de los especialistas de la salud oral (cirujanos orales y maxilofaciales, odontólogos y estomatólogos). Los objetivos del presente artículo son explicitar las medidas preventivas más apropiadas para limitar el número de casos de esta patología, a la luz de los conocimientos actuales, detallar la forma de tratamiento más reconocida para los diferentes estadios de la osteonecrosis, una vez establecida así como proporcionar un documento para la buena praxis médica y odontológica en los pacientes que padecen esta enfermedad o estén en riesgo de sufrirla. Este documento ha sido aprobado por la Comisión Científica de la SECOM.
\end{abstract}

Palabras clave: Bisfosfonatos; Osteonecrosis maxilar; Osteoporosis.

Recibido: 29.05 .08

Aceptado: 16.06 .08

\begin{abstract}
The bisphosphonates are stable inorganic pyrophosphate analogs that have demonstrated their efficacy in the treatment of a variety of pathologies, such as osteolytic lesions associated with bony metastases or multiple myeloma, malignant hypercalcemia, Paget's disease, and osteoporosis. Currently, two disease entities supported by different degrees of scientific evidence can be characterized, at least academically: osteonecrosis associated with intravenous bisphosphonate administration and osteonecrosis associated with oral bisphosphonate administration. Prevention and treatment strategies are being consolidated for jaw necrosis associated with intravenous bisphosphonate use, but more scientific documentation is needed for the condition associated with oral bisphosphonate use. Our aim is to facilitate the clinical and complementary diagnosis of bisphosphonate associated osteonecrosis by oral health specialists (oral and maxillofacial surgeons, dentists, and stomatologists). The objectives of the present article were to describe the most appropriate preventive measures for limiting the number of cases of this pathology in the light of current knowledge, to detail the best recognized form of treatment for different stages of jaw osteonecrosis, and, for established jaw osteonecrosis, to describe good medical and dentistry practice for patients who suffer this disease or are at risk of suffering it. This document was approved by the SECOM Scientific Commission.
\end{abstract}

Key words: Bisphosphonates; Osteonecrosis of the jaw; Osteoporosis.

\footnotetext{
* Este documento fue aprobado el día 22 de mayo del 2008, por la Comisión Científica de la SECOM, compuesta por los Dres. Acero J, Burgueño M, de Vicente JC, Martín-Granizo R, Santamaría J, Infante P, Raspall G. y López Cedrún JL.
}

\section{Correspondencia:}

R. Martín-Granizo

SECOM

C/ Corazón de María, $252^{\circ} \mathrm{E}$

28002 Madrid

Email: rmartin.hcsc@salud.madrid.org 


\section{Introducción}

Los bisfosfonatos son análogos estables de los pirofosfatos inorgánicos que han demostrado su eficacia para el tratamiento de diversas patologías, como las lesiones osteolíticas asociadas a metástasis óseas o al mieloma múltiple, la hipercalcemia maligna, la enfermedad de Paget y la osteoporosis. Es importante para el clínico conocer los diferentes tipos de aminobisfosfonatos comercializados, así como su potencia relativa. En la tabla 1 se recopilan las principales características de los fármacos actualmente autorizados y su nombre comercial aunque la industria está en continua evolución. La constatación, en la pertinente historia clínica, de la utilización de alguno de estos fármacos, constituye el punto de partida de todas las medidas de diagnóstico y profilaxis de la osteonecrosis de los maxilares en relación con el empleo de bisfosfonatos (OMRB).

A finales del año 2003 y comienzos del 2004 se recogieron en la literatura científica los primeros casos que evidenciaban una asociación entre la administración de aminobisfosfonatos intravenosos y la presentación de exposiciones óseas de evolución tórpida en los huesos maxilares. En la actualidad se podría hablar, al menos académicamente, de dos entidades con diferentes grados de información científica: las osteonecrosis en relación con la administración intravenosa de estos medicamentos y las osteonecrosis en relación con la administración oral de los mismos. Para el primer grupo las estrategias de prevención y tratamiento empiezan a estar consolidadas, mientras que para el segundo se precisará de una mayor documentación científica para alcanzar este objetivo. En la tabla 2 se recogen las principales diferencias entre estas dos entidades.

\section{Factores de riesgo}

Los factores de riesgo que se relacionan con la presentación de las OMRB pueden simplificarse de la siguiente manera:

1. Los pacientes con mieloma múltiple (MM) tienen el mayor riesgo de presentación de OMRB, que se incrementa un 9\% por cada década que aumente la edad. En segundo lugar estarían las pacientes con cáncer de mama.

2. Los pacientes con tratamiento concomitante con corticoesteroides parecen tener un mayor riesgo de osteonecrosis.

3. La vía intravenosa en pacientes oncológicos, los bisfosfonatos de mayor potencia (ácido zoledrónico), y un mayor tiempo de empleo y/o dosis se asocian con una mayor frecuencia de presentación de OMRB.

4. Las osteonecrosis suelen presentarse en pacientes que han tomado bisfosfonatos orales durante más de tres años, con un tiempo medio de consumo de 5,6 años (rango: 3,3-10,2 años). En cambio, el tiempo de utilización de los pacientes con osteonecrosis en relación con los bisfosfonatos intravenosos puede ser inferior a 1 año (9,3 meses para el ácido zoledrónico y 14,1 meses para el pamidronato).

5. En las osteonecrosis en relación con los aminobisfosfonatos intravenosos los antecedentes de cirugía dentoalveolar multiplican por siete la posibilidad de presentación de OMRB, mientras la

\section{Introduction}

The bisphosphonates are stable inorganic pyrophosphate analogs that have demonstrated their efficacy in the treatment of a variety of pathologies, such as osteolytic lesions associated with bony metastases or multiple myeloma, malignant hypercalcemia, Paget's disease, and osteoporosis. It is important that health care professionals be familiar with the different types and relative strength of the aminobisphosphonates available on the market. The principal characteristics of the drugs now authorized and their commercial names are listed in table I. However, the industry is continuously evolving. The notation in the pertinent medical record of the use of any of these drugs is the starting point for all diagnostic and prophylactic measures for bisphosphonate associated osteonecrosis of the jaw (BAONJ).

In the end of 2003 and beginning of 2004, the first cases were published in the scientific literature that showed an association between the administration of intravenous aminobisphosphonates and slowly developing exposure of the maxillary bone. Currently, two disease entities supported by different degrees of scientific evidence can be characterized, at least academically: osteonecrosis associated with intravenous bisphosphonate administration and osteonecrosis associated with oral bisphosphonate administration. Prevention and treatment strategies are being consolidated for jaw necrosis associated with intravenous bisphosphonate use, but more scientific documentation is needed for the condition associated with oral bisphosphonate use. The main differences between these two conditions are summarized in table II.

\section{Risk factors}

The risk factors related with the occurrence of BAONJ can be summarized as follows:

1. Patients with multiple myeloma (MM) are at greater risk of presenting BAONJ and the risk increases by $9 \%$ with every ten-year increase in age. Breast cancer is the second risk factor.

2. Patients receiving concomitant treatment with corticosteroids appear to have a greater risk of osteonecrosis.

3. Intravenous administration of bisphosphonates to patients with neoplasms, use of stronger bisphosphonates (zoledronic acid), and more prolonged use and/or higher doses are associated with a greater frequency of presentation of BAONJ.

4. Osteonecrosis usually occurs in patients who have taken oral bisphosphonates for more than three years. The mean duration of bisphosphonate use is 5.6 years (range: 3.3-10.2 years). However, some patients with intravenous bisphosphonate-associated osteonecrosis of the jaw have been treated for less than 1 year (9.3 months for zoledronic acid and 14.1 months for pamidronate). 
Tabla 1. Principales bisfosfonatos, vía de administración y potencia relativa

\begin{tabular}{|c|c|c|c|c|}
\hline Nombre genérico & Nombre comercial & Vía de administración & Casa comercial & Potencia relativa \\
\hline Pamidronato & $\begin{array}{l}\text { Aredia } ® \\
\text { Linoten } ® \\
\text { Pamifos } ®\end{array}$ & Intravenosa & $\begin{array}{l}\text { Novartis } \\
\text { Mayne } \\
\text { Madaus }\end{array}$ & 100 \\
\hline Ácido zoledrónico & $\begin{array}{l}\text { Zometa® } \\
\text { Aclasta® }\end{array}$ & Intravenosa & $\begin{array}{l}\text { Novartis } \\
\text { Novartis }\end{array}$ & 100.000 \\
\hline Alendronato & $\begin{array}{l}\text { Fosamax }{ }^{\circledR} \\
\text { Adronat }{ }^{\circledR} \\
\text { Fosavance } \circledR\end{array}$ & Oral & $\begin{array}{l}\text { Merck } \\
\text { Abello } \\
\text { Merck }\end{array}$ & 1.000 \\
\hline Etidronato & $\begin{array}{l}\text { Didronel }{ }^{\circledR} \\
\text { Difosfen }{ }^{\circledR} \\
\text { Osteum }{ }^{\circledR}\end{array}$ & Oral & $\begin{array}{l}\text { Procter-Gamble } \\
\text { Rubio } \\
\text { Viñas }\end{array}$ & 1 \\
\hline Risedronato & $\begin{array}{l}\text { Actonel® } \\
\text { Acrel }{ }^{\circledR} \\
\text { Losentra }{ }^{\circledR}\end{array}$ & Oral & $\begin{array}{l}\text { Proctor-Gamble } \\
\text { P\&G Pharmaceuticals } \\
\text { Aventis }\end{array}$ & 5.000 \\
\hline Tiludronato & Skelid $®$ & Oral & Sanofi & 10 \\
\hline Ibandronato & $\begin{array}{l}\text { Boniva® } \\
\text { Bonviva® }\end{array}$ & $\begin{array}{l}\text { Oral } \\
\text { Intravenoso }\end{array}$ & $\begin{array}{l}\text { Roche } \\
\text { Roche }\end{array}$ & 10.000 \\
\hline
\end{tabular}

Table 1. Principal bisphosphonates, route of administration, and relative strength

\begin{tabular}{|c|c|c|c|c|}
\hline Generic name & Trade name & Route of administration & Manufacturer & Relative strength \\
\hline Pamidronate & $\begin{array}{l}\text { Aredia } ® \\
\text { Linoten } ® \\
\text { Pamifos } ®\end{array}$ & Intravenous & $\begin{array}{l}\text { Novartis } \\
\text { Mayne } \\
\text { Madaus }\end{array}$ & 100 \\
\hline Zoledronic acid & $\begin{array}{l}\text { Zometa }{ }^{\circledR} \\
\text { Aclasta }{ }^{\circ}\end{array}$ & Intravenous & $\begin{array}{l}\text { Novartis } \\
\text { Novartis }\end{array}$ & 100.000 \\
\hline Alendronate & $\begin{array}{l}\text { Fosamax }{ }^{\circledR} \\
\text { Adronat® } \\
\text { Fosavance } ®\end{array}$ & Oral & $\begin{array}{l}\text { Merck } \\
\text { Abello } \\
\text { Merck }\end{array}$ & 1.000 \\
\hline Etidronate & $\begin{array}{l}\text { Didronel }{ }^{\circledR} \\
\text { Difosfen }{ }^{\circledR} \\
\text { Osteum }{ }^{\circledR}\end{array}$ & Oral & $\begin{array}{l}\text { Procter-Gamble } \\
\text { Rubio } \\
\text { Viñas }\end{array}$ & 1 \\
\hline Risedronate & $\begin{array}{l}\text { Actonel } \circledast \\
\text { Acrel }{ }^{\circledR} \\
\text { Losentra } \circledast\end{array}$ & Oral & $\begin{array}{l}\text { Proctor-Gamble } \\
\text { P\&G Pharmaceuticals } \\
\text { Aventis }\end{array}$ & 5.000 \\
\hline Tiludronate & Skelid® & Oral & Sanofi & 10 \\
\hline Ibandronate & $\begin{array}{l}\text { Boniva } \AA \\
\text { Bonviva }{ }^{\circledR}\end{array}$ & $\begin{array}{l}\text { Oral } \\
\text { Intravenous }\end{array}$ & $\begin{array}{l}\text { Roche } \\
\text { Roche }\end{array}$ & 10.000 \\
\hline
\end{tabular}

presencia de patología inflamatoria (dental o periodontal) incrementa en el mismo porcentaje esta posibilidad.

6. En las osteonecrosis en relación con aminobisfosfonatos orales, mucho más infrecuentes, el $50 \%$ de los casos se presentan espontáneamente (sin antecendentes de cirugía dentoalveolar), localizándose mayoritariamente en los segmentos posteriores de la mandíbula.

7. Los efectos de los aminobisfosfonatos intravenosos sobre el hueso pueden persistir incluso 10 años después de suspendido el tratamiento.
5. In osteonecrosis of the jaw associated with intravenous aminobisphosphonates, a history of dentoalveolar surgery multiplies seven-fold the possibility of BAONJ occurrence. The presence of inflammatory oral disease (dental or periodontal) increases the possibility similarly.

6. In osteonecrosis of the jaw associated with oral aminobisphosphonate use, which is much less frequent, 50\% of cases occur spontaneously (in the absence of history of dentoalveolar surgery). The primary locating is the posterior mandible. 
Tabla 2. Principales diferencias entre las osteonecrosis por aminobisfosfonatos orales e intravenosos

$\begin{array}{lll} & \text { Bisfosfonatos intravenosos } & \text { Bisfosfonatos orales } \\ \text { Incidencia } & \text { Relativamente frecuente: } 0,8-12 \% & \text { Muy infrecuente: } 0,01-0,04 \% \\ \text { Tiempo de adminitración } & \text { Corto: } 9,3-14,1 \text { meses } & \text { Largo: 3,3-10,2 años } \\ \text { Localización } & \text { Mandíbula / maxilar superior / ambos } & \\ \text { Sectores posteriores } & \text { Mayoritariamente en mandíbula } & \text { Menor tamaño } \\ \text { Tamaño de exposición } & \text { Habitualmente mayor tamaño } & 50 \% \text { de los casos } \\ \text { Antecedente quirúrgico } & 70 \% \text { de los casos } & \text { Más favorable } \\ \text { Evolución } & \text { Impredecible. Sucesión de estadios } & \end{array}$

Table 2. Main differences between osteonecrosis of the jaw associated with oral and intravenous aminobisphosphonate use

\author{
Incidence \\ Duration of administration \\ Location \\ Posterior segments \\ Size of jawbone exposure \\ History of surgery \\ Outcome
}

\section{Bintravenous bisphosphonates}

Relatively frequent: $0.8-12 \%$

Short: 9.3- 14.1 months

Mandible / maxilla / both

Mainly mandibular

Generally larger

$70 \%$ of cases

Unpredictable. Succession of stages
Oral bisphosphonates

Very uncommon: 0.01-0.04\%

Prolonged: 3.3-10.2 years

Smaller

$50 \%$ of cases

More favorable
8. La utilización de aminobisfosfonatos intravenosos para las indicaciones clásicas de los orales (osteoporosis, prevención de fracturas de cadera y vertebrales: Zometa, $5 \mathrm{mg}$ una dosis anual, durante tres años), parece tener el mismo comportamiento con respecto a las osteonecrosis que el empleo de bisfosfonatos orales.

9. Otros tratamientos o enfermedades concurrentes (Diabetes, Tabaco, Alcohol, Higiene oral, Quimioterapia...), pueden suponer un incremento en el riesgo.

\section{Objetivos}

1. Facilitar el diagnóstico clínico y complementario de las osteonecrosis por bisfosfonatos por parte de los especialistas de la salud oral (cirujanos orales y maxilofaciales, odontólogos y estomatólogos).

2. Explicitar las medidas preventivas más apropiadas para limitar el número de casos de esta patología, a la luz de los conocimientos actuales.

3. Detallar la forma de tratamiento más reconocida para los diferentes estadios de la osteonecrosis, una vez establecida.

4. Proporcionar un documento para la buena praxis médica y odontológica en los pacientes que padecen esta enfermedad o estén en riesgo de sufrirla.

\section{Criterios diagnósticos. Definición de caso}

Al objeto de diferenciar la osteonecrosis de los maxilares en relación con bisfosfonatos (OMRB) de otras patologías que cursen con
7. The effects of intravenous aminobisphosphonates on bone can persist up to 10 years after suspending treatment.

8. The use of intravenous aminobisphosphonates for indications in which oral products are traditional used (osteoporosis, prevention of hip and vertebral fractures: Zometa, annual dose of $5 \mathrm{mg}$ during three years) seems to act similarly with respect to jaw osteonecrosis as the use of oral bisphosphonates.

9. Concurrent therapies or diseases (diabetes, smoking, alcohol abuse, poor oral hygiene, chemotherapy, and others) can increase risk.

\section{Objectives}

1. Our aim is to facilitate the clinical and complementary diagnosis of bisphosphonate associated osteonecrosis by oral health specialists (oral and maxillofacial surgeons, dentists, and stomatologists).

2. To explain the most appropriate preventive measures for limiting the number of cases of this pathology in the light of present knowledge.

3. To detail the most recognized form of treatment for different stages of osteonecrosis once it has become established.

4. To offer guidelines for good medical and dental practice for the management of patients who suffer this disease or are at risk of suffering it. 

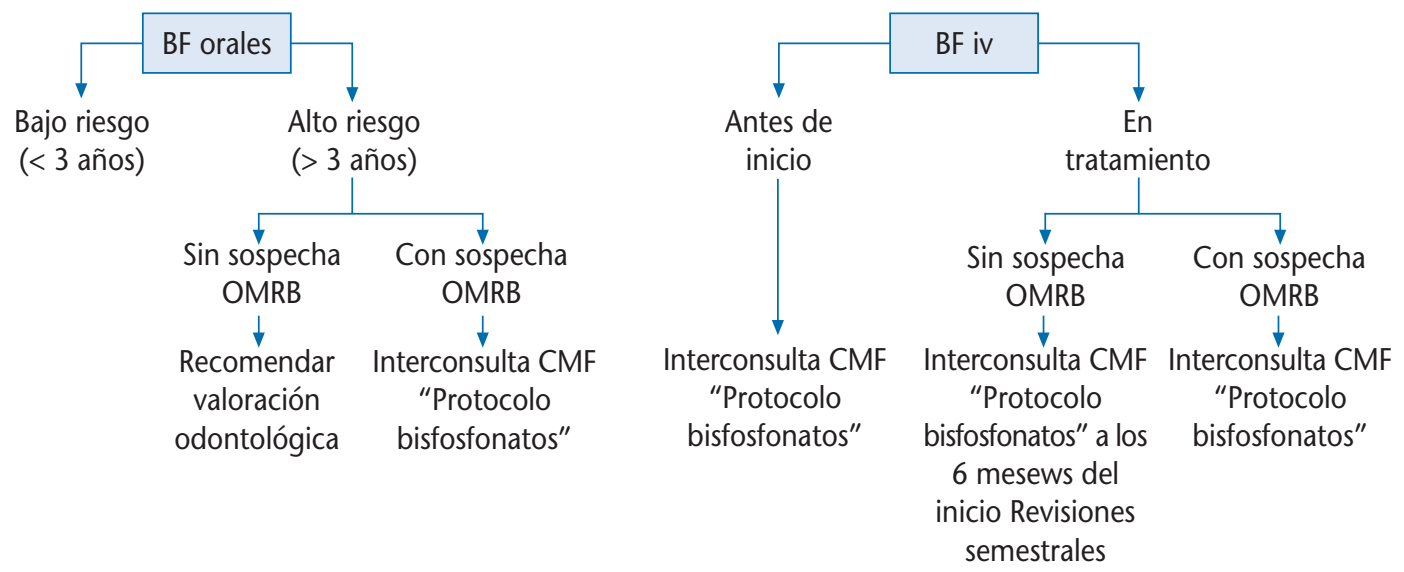

Figura 1. Algoritmo del protocolo diagnóstico.

Figure 1. Algorithm of diagnostic protocol

exposiciones óseas y retrasos en la cicatrización de los procesos alveolares, se deben de tener en cuenta los siguientes criterios de diagnóstico e inclusión (Fig. 1):

\section{Criterios clínicos}

1. Paciente que ha recibido, está recibiendo o recibió bisfosfonatos intravenosos $u$ orales sin antecedentes previos de radioterapia en el territorio maxilofacial. La existencia de un antecedente previo de radioterapia cérvico-facial conllevará un diagnóstico diferencial comprometido entre una osteonecrosis física, química o mixta.

2. Presencia de una o varias lesiones ulceradas con exposición ósea en el maxilar superior y/o la mandíbula de más de ocho semanas de evolución (AAOMS, 2006).

3. Esta exposición ósea puede ser asintomática y autolimitada en su tamaño, o acompañarse de dolor, aumento en su extensión y formación de secuestros óseos (Fig. 2).

4. Algunos casos de OMRB pueden presentarse sin una exposición ósea franca, predominando el dolor de origen no filiado, con o sin pequeñas fístulas orales.

\section{Pruebas complementarias}

1. Ortopantomografía (Fig. 3). Técnica de imagen más utilizada. Puede no aportar información en estadios precoces de la OMRB.

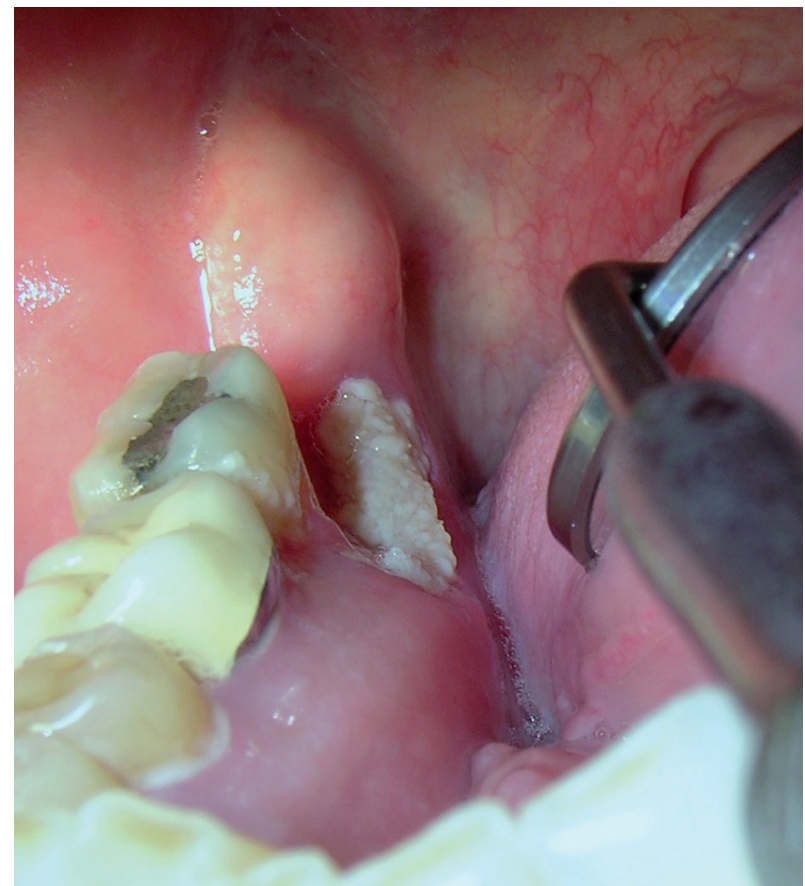

Figura 2. Exposición ósea a nivel de la cortical lingual mandibular, con secuestro óseo (cortesía Dra. MA. González Corchón).

Figure 2. Exposure of mandibular lingual cortical bone with sequestration.

\section{Diagnostic criteria. Case definition}

The following diagnostic and inclusion criteria should be considered for the purpose of differentiating bisphosphonateassociated osteonecrosis of the jaw (BAONJ) from other pathologies that course with bone exposure and delayed healing of alveolar processes (Fig. 1):

\section{Clinical criteria}

1. A patient who has received, is receiving, or formerly received intravenous or oral bisphosphonates without a previous history of irradiation of the maxillofacial region. The existence of a previous history of cervico-facial irradiation requires a meticulous differential diagnosis between osteonecrosis of physical, chemical, or mixed origin.

2. The presence of one or more ulcerated lesions with exposed upper maxillary and/or mandibular bone of more than eight weeks of evolution (AAOMS, 2006).

3. Bone exposure may be asymptomatic and self-limited in size, or accompanied by pain, growing extension, and bone sequestration (Fig. 2).

4. Some cases of BAONJ may present without frank bone exposure; in these cases, unaffiliated pain predominates, with or without small oral fistulas. 
2. Tomografía Computarizada (TC) (Fig. 4). Puede posibilitar un diagnóstico precoz, y definir la verdadera extensión de la osteonecrosis, confirmando también el estadio clínico y, por lo tanto, orientando hacia el tratamiento específico para cada caso. La Resonancia Nuclear Magnética (RM) una técnica complementaria para valorar la afectación del hueso medular y partes blandas.

3. Cultivos microbiológicos y antibiograma.

\section{Estudio histológico. Biopsia}

1. La biopsia del hueso expuesto se hará obligatoriamente ante la sospecha de que el origen de la lesión guarde relación con la patología que motivó la utilización intravenosa de los bisfosfonatos, de modo primario o metastático, especialmente si se trata de enfermos con antecedentes de mieloma múltiple.

2. En los pacientes en tratamiento con bisfosfonatos orales se deberá hacer una biopsia ante la mínima sospechosa clínica de que se trate de un carcinoma epidermoide oral, de acuerdo con las indicaciones habituales en estos casos.

\section{Prevención de la patología}

\section{Bisfosfonatos intravenosos en pacien- tes oncológicos}

Una de las teorías patogénicas del ONRB es el depósito del fármaco en los osteoclastos, que explica por qué la dosis acumulada es un factor de riesgo en relación directa y por qué se puede encontrar ONRB en pacientes que han suspendido el tratamiento hace años. Por otro lado, no se han publicado casos por debajo de los 6 meses de administración del fármaco. Por esto, podríamos considerar que el hueso durante las primeras semanas de tratamiento se comporta como sano, con idéntica capacidad de regeneración. Proponemos por tanto que no se contraindiquen los procedimientos invasivos que puedan ser necesarios durante los primeros 3 meses. Hay

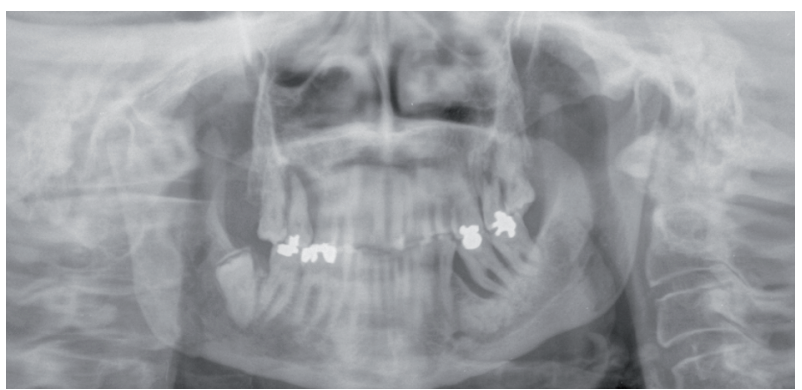

Figura 3. Ortopantomografía, donde se observa el patrón radiológico de osteonecrosis en la región molar izquierda de la mandíbula (cortesía de los Dres. JM. García Rielo y A. López Davis) Figure 3. Orthopantomography showing a radiologic image of osteonecrosis in the left molar region of the mandible
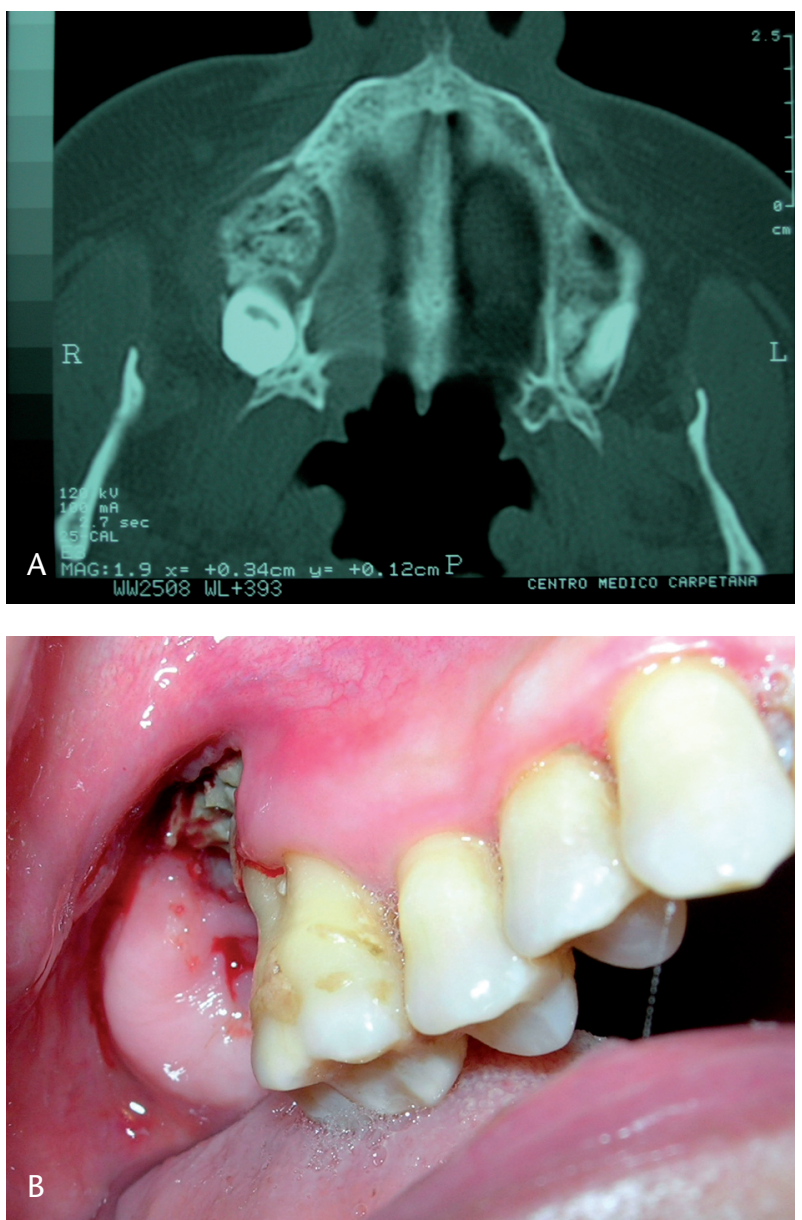

Figura 4. A) TC donde se observa una zona de secuestro óseo bien delimitada en el área maxilar superior derecha. B) Imagen clínica del mismo caso (cortesía Dr. J. Acero).

Figure 4. CT showing a well-delimited area of bone sequestration in the upper right maxilla. B. Clinical image of the same case.
Complementary tests

1. Orthopantomography. This is the imaging technique most often used. It may not provide diagnostic information in the early stages of BAONJ (Fig. 3).

2. Computed tomography (CT) (Fig. 4). CT may allow early diagnosis and define the true extension of the osteonecrosis. It also may confirm the clinical stage and provide guidance for the specific treatment of each case. Magnetic resonance imaging (MRI) is a complementary technique for assessing the involvement of bone marrow and soft tissues.

3. Microbiologic culture and antibiotic susceptibility testing.

\section{Histologic study. Biopsy}

1. Biopsy of the exposed bone is obligatory whenever the origin of the lesion is suspected to be related to the pathology that motivated intravenous use of bisphosphonates, whether this is a primary tumor or metastasis, especially in patients with multiple myeloma.

2. In patients being treated with oral bisphosphonates, biopsy should be performed whenever there is any clinical suspicion that oral squamous-cell carcinoma is present, in accordance with the usual indications in such cases.

\section{Prevention of osteonecrosis of the jaw}

Intravenous bisphosphonate administration to patients with neoplasms

One of the pathogenic theories of $B A O N J$ is that the drug is deposited in osteoclasts. This would explain why cumu- 
que tener en cuenta que la situación clínica de base de estos pacientes hace necesario el inicio inmediato del tratamiento por lo que este no podría diferirse por aplicar las medidas preventivas (hipercalcemia maligna, mieloma, metástasis osteolíticas, etc.).

\section{Antes y durante los tres primeros meses de la administración del tratamiento intravenoso (AAOMS, 2007)}

1. Los diferentes especialistas (oncólogos, hematólogos, ginecólogos, urólogos, etc.) deberían informar al paciente y su entorno sobre la importancia del mantenimiento de la salud bucal con relación al tratamiento y solicitar una valoración del paciente por parte del especialista en cirugía oral y maxilofacial o del odontólogo o estomatologo, antes del inicio del tratamiento.

2. El especialista en salud oral deberá diagnosticar la existencia de focos infecciosos, tanto dento-alveolares como periodontales, presentes o futuros y recomendar y proceder a su inmediato tratamiento. Si precisara la realización de exodoncias deberá empezar su plan de tratamiento con este acto quirúrgico, al objeto de generar un intervalo de tiempo prudencial (15-20 días) entre la exodoncia y la primera administración intravenosa del bisfosfonato. Deberán ser exodonciados los dientes con un pronóstico incierto.

3. Respecto a la colocación de implantes intraóseos, no hay una recomendación explicita que lo contraindique ni case reports en que se demuestre asociación entre un implante correctamente osteointegrado y ONRB. No se recomienda la colocación de implantes antes de la administración IV de bisfosfonatos si se espera que no haya finalizado el periodo de osteo-integración en ese momento.

4. El odontólogo/ estomatólogo deberá realizar todos los tratamientos no invasivos apropiados para alcanzar un buen nivel de salud oral, informando al paciente y a su entorno sobre la importancia de este objetivo como principal medida profiláctica de la OMRB. Estos tratamientos conservadores pueden realizarse durante la administración del bisfosfonato.

5. El dentista deberá evaluar y corregir la posible existencia de traumatismos protéticos, especialmente sobre las superficies linguales de la mandíbula. También debe evaluar y corregir la posible presencia de tori, exóstosis de gran tamaño y otras prominencias óseas en caso de riesgo de futuras complicaciones, especialmente en pacientes con prótesis removibles.

6. El dentista y el especialista médico, bajo cuyo criterio se instaurará el tratamiento intravenoso del aminobisfosfonato, deberán informar y concienciar al paciente sobre los riesgos relacionados con la cirugía dentoalveolar una vez que se ha instaurado el tratamiento así como sobre la persistencia del riesgo de OMRB durante un largo periodo de tiempo después de su aplicación.

\section{Durante la administración del tratamiento intravenoso (después de los primeros 3 meses de tratamiento)}

1. Deberá evitarse la realización de cualquier tipo de cirugía oral e implantológica.

2. Ante la presencia de un foco infeccioso el tratamiento de los conductos debe ser la primera indicación, procurando un míni- lative dose is a directly related risk factor and why BAONJ occurs in patients who stopped treatment years earlier. On the other hand, no cases have been published in which the drug was administered for less than 6 months. Consequently, we can assume that during the first weeks of bisphosphonate treatment the behavior of the bone is healthy and it has good regeneration capacity. We propose, therefore, that any invasive procedures that may be required in the first 3 months of bisphosphonate administration should not be contraindicated. It should be remembered that the underlying clinical situation of these patients requires immediate initiation of treatment and preventive measures must not be deferred (malignant hypercalcemia, myeloma, osteolytic metastases, and others).

Before and during the first three months of administration of intravenous bisphosphonates

(AAOMS, 2007)

1. Specialists (oncologists, hematologists, gynecologists, urologists, etc.) must inform the patient and those close to the patient about the importance of maintaining oral health while receiving this treatment. The patient should be examined by a specialist in oral and maxillofacial surgery, dentist, or stomatologist before beginning treatment.

2. The oral health specialist should identify any infective foci, whether dentoalveolar or periodontal, that are present or may appear in the future, and prescribe and carry out treatment immediately. If tooth extraction is needed, the therapeutic strategy should begin at the time of this surgical act in order to establish a prudent time interval (15-20 days) between tooth extraction and the first intravenous bisphosphonate dose. Teeth with an uncertain prognosis should be removed.

3. There are no explicit recommendations that contraindicate the placement of intraosseous implants, nor have there been case reports of any association between properly osteointegrated implants and BAONJ. The insertion of dental implants before the i.v. administration of bisphosphonates is not recommended if the osteointegration period is not expected to have concluded before bisphosphonate use.

4. The dentist/stomatologist must perform all appropriate noninvasive treatments to ensure a good level of oral health and inform the patient and those close to the patient about the importance of oral health as the primary prophylactic measure against BAONJ. Conservative procedures can be performed during bisphosphonate administration.

5. The dentist should evaluate and correct a potential prosthetic trauma, especially on the lingual surfaces of the mandible. The possible presence of tori, large exostoses, and other bony prominences must be evaluated and corrected to prevent future complications, especially in patients with removable dental prostheses. 
mo trauma periapical y periodontal. Valorar cobertura antibiótica.

3. El dentista deberá controlar periódicamente el estado de salud oral del paciente, manteniendo sus condiciones óptimas. Se recomiendan controles al menos cada seis meses.

\section{Después del tratamiento intravenoso}

1. Deberá evitarse la realización de cualquier tipo de cirugía oral al menos durante un periodo no inferior a los 10 años de la última administración del bisfosfonato. Aunque es cierto que se ha demostrado la presencia de zoledrónico hasta 12 años después, no hay datos al respecto en la literatura de referencia y este punto permanece controvertido.

2. El dentista deberá motivar y mantener un riguroso control de la salud oral del paciente, durante largo tiempo.

\section{Bisfosfonatos orales o bisfosfonatos intravenosos (Zometa) a una dosis anual durante tres años}

\section{Antes de la administración del tratamiento oral}

1. Los diferentes especialistas que prescriben el tratamiento deben informar y recomendar a sus pacientes la evaluación de su salud oral antes del inicio del tratamiento.

2. Los especialistas en salud oral tienen un plazo de 3 años para alcanzar un óptimo estado de salud oral. Durante este periodo se podrá realizar todo tipo de tratamiento quirúrgico y rehabilitador, comenzando por los que requieran un mayor compromiso en el remodelado óseo.

\section{Durante la administración del tratamiento oral}

(Debido al escaso nivel de evidencia disponible, las recomendaciones referentes a este tipo de administración oral deberán ser actualizadas constantemente).

Pacientes con menos de tres años de tratamiento y sin factores de riesgo:

1. Los especialistas de la salud oral podrán realizar cualquier tipo de tratamiento quirúrgico y rehabilitador (implantología) que requiera el buen cuidado de su paciente.

2. Se deberá obtener un consentimiento informado que añada a los riesgos propios de cada cirugía, la osteonecrosis en relación con la ingesta del bisfosfonato oral.

3. Se deberá controlar periódicamente (al menos anualmente) el estado de salud oral.

Pacientes con menos de tres años de tratamiento, con factores de riesgo: administración concomitante de corticoides, edad por encima de los 70 años.

1. Sería recomendable, si las condiciones clínicas lo permiten, la suspensión del medicamento durante un periodo de tres meses antes de la realización de cualquier tipo de cirugía oral.

2. La reincorporación del tratamiento se realizará cuando la cicatrización de la cirugía efectuada haya concluido. En el caso de
6. The dentist and medical specialist who are prescribing intravenous aminobisphosphonate treatment must inform the patient so that he or she is aware of the risks of dentoalveolar surgery once bisphosphonate treatment has been begun. The patient should also understand that the risk of BAONJ persists for a long time after bisphosphonate administration.

During intravenous bisphosphonate administration (after the first 3 months of treatment)

1. Any type of oral or dental implant surgery must be avoided.

2. If an infective focus appears, the first indication is to treat the condition with minimal periapical and periodontal trauma. Assess antibiotic coverage.

3. The dentist should regularly examine the patient's mouth and maintain optimal oral health. Follow-up examinations at least once every six months are recommended.

After intravenous bisphosphonate administration

1. Oral surgery of any type should be avoided for a period of no less than 10 years after the last injection of bisphosphonate. Although the presence of zoledronic acid up to 12 years after administration has been demonstrated, there are no data on the topic in the reference literature and this point is still under debate.

2. The dentist must encourage the patient to be vigilant and maintain strict oral hygiene for many years.

Annual doses of oral or intravenous bisphosphonates (Zometa) for three years

Before oral bisphosphonate administration

1. The different specialists who prescribe treatment must inform their patients and advise them to have an oral health assessment before beginning treatment.

2. Oral health specialists have a period of 3 years to achieve an optimal state of oral health. During this period, any type of surgical and rehabilitative treatment can be undertaken. Procedures involving more bone remodeling should be performed first.

\section{During oral bisphosphonate administration}

(Due to the limited evidence currently available, recommendations for oral bisphosphonate administration should be updated regularly.)

Patients with fewer than three years of bisphosphonate administration and no risk factors

1. Oral health specialists can perform any type of surgical and rehabilitative treatment (dental implants) that proper care of the patient requires. 

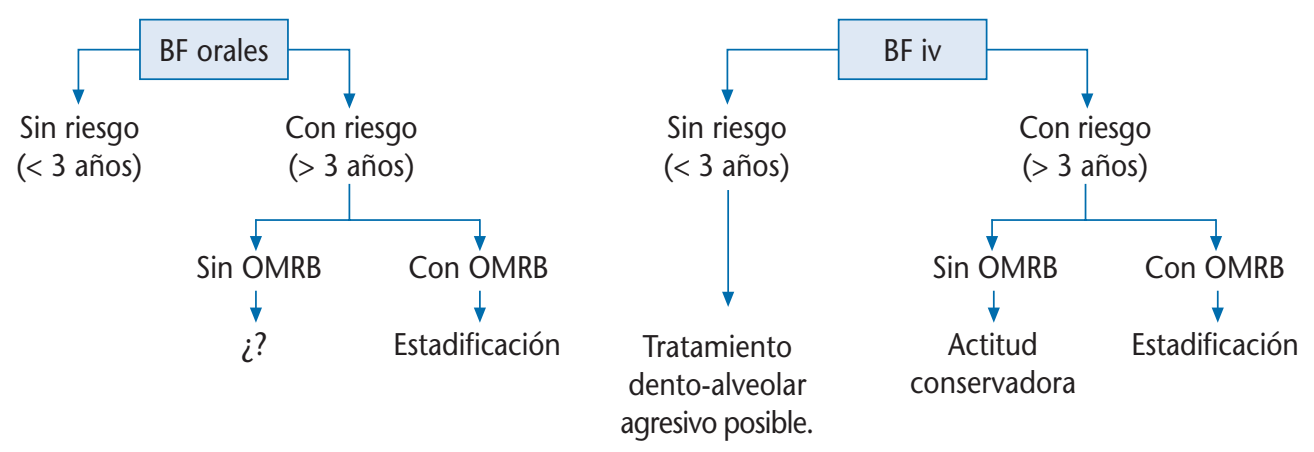

Figura 5. Algoritmo del protocolo terapéutico.

Figure 5. Algorithm of therapeutic protocol

la cirugía implantológica se recomienda un plazo mínimo de tres meses.

3. La determinación sanguínea en ayunas del telopéptido C-terminal del colágeno tipo I (b-CTx) que rinda valores superiores a $150 \mathrm{pg} / \mathrm{mL}$ permitiría realizar cualquier tipo de cirugía con mínimo riesgo y sin la necesidad de suspender el aminobisfosfonato. Sin embargo, este parámetro precisa de mayor evidencia científica para confirmar su validez.

4. Aunque es posible que la cirugía en el maxilar superior tenga una significativa menor incidencia de osteonecrosis, esto se encuentra pendiente de una mayor evidencia científica, por lo que no podemos afirmar que las actuaciones agresivas sobre el maxilar no incrementen el riesgo de OMRB en esa localización.

5. Se debe obtener un consentimiento informado que añada a los riesgos propios de cada cirugía, la osteonecrosis en relación con la ingesta del bisfosfonato oral.

6. Controlar periódicamente (al menos anualmente) el estado de salud oral.

Pacientes con más de tres años de tratamiento, con o sin factores de riesgo.

1. Las mismas recomendaciones que en el grupo precedente.

\section{Tratamiento de la patología instaurada (Fig. 5)}

Estadio 1: exposición de hueso necrótico, asintomática y sin signos de infección

1. Cuantificación en milímetros del tamaño de la exposición.

2. Sugerir, si fuera posible, la suspensión del aminobisfosfonato por parte del especialista que lo prescribió.

3. Pautar enjuagues con colutorio de clorhexidina al $0,12 \%$ o al $0,2 \%$ cada 12 horas durante 15 días.

4. Control evolutivo a los 15 días:

- Igual o menor tamaño de exposición que en el momento del diagnóstico: mantener la misma pauta durante otros 15 días.

- Incremento en el tamaño de la exposición, dolor o signos de infección: aplicar el tratamiento de estadio 2.

5. Control evolutivo al mes:
2. Informed consent must be obtained in which the risk of osteonecrosis of the jaw related to oral bisphosphonate use is explicitly mentioned as a risk inherent to each intervention.

3. The patient's oral health should be followed up regularly (at least once a year).

Patients with fewer than three years of bisphosphonate administration, with risk factors: concomitant corticoid administration, age over 70 years.

1. It would be advisable, if clinical circumstances allow, to discontinue corticoid administration for a period of three months before performing any type of oral surgery.

2. Treatment may be resumed when the surgical wound has healed. In the case of dental implant surgery, a minimum period of three months is recommended.

3. The finding in fasting blood samples of serum cross-linked $C$-terminal telopeptide of type I collagen (b-CTX) of values above $150 \mathrm{pg} / \mathrm{mL}$ allow any type of surgery to be performed with minimal risk and without having to discontinue aminobisphosphonate use. Nevertheless, this parameter still requires more scientific evidence to confirm its validity.

4. Although surgery of the upper maxilla may have a significantly lower incidence of osteonecrosis of the jaw, this claim is pending confirmation by scientific evidence. Consequently, we cannot state that aggressive maxillary interventions do not increase the risk of BAONJ in the upper jaw.

5. Informed consent must be obtained in which osteonecrosis of the jaw related to oral bisphosphonate use is explicitly mentioned as one of the risks inherent to each intervention.

6. The patient's oral health should be followed up regularly (at least once a year).

Patients with more than three years of bisphosphonate administration, with or without risk factors:

1. The recommendations are the same as for the patients in the previous group. 
- Mejoría o resolución: sugerir al especialista correspondiente la restauración del aminobisfosfonato si la situación clínica del paciente lo aconseja. Aplicar rigurosamente las normas de prevención.

- Incremento en el tamaño de la exposición, dolor o signos de infección: aplicar el tratamiento de estadio 2.

Estadio 2: exposición de hueso necrótico, en pacientes con dolor y signos de infección. Podría incluirse en este estadio a aquellos pacientes con proceso doloroso en los maxilares no atribuible a otra causa y con signos radiológicos de osteonecrosis. No se aplicaría en estos casos el punto 1 de las siguientes recomendaciones (Fig. 6).

1. Cuantificación en milímetros del tamaño de la exposición.

2. Recomendar, si fuera posible, la suspensión del aminobisfosfonato por parte del especialista que lo prescribió.

3. Pautar enjuagues con colutorio de clorhexidina al $0,12 \%$ o al $0,2 \%$ cada 12 horas durante 15 días.

4. Administrar antibioterapia oral de manera empírica (mientras no se disponga de resultados de cultivo y antiobiograma):

- Primera indicación: Amoxicilina/ácido clavulánico 2.000/125 mgrs. cada 12 horas, durante 15 días. En los protocolos de EEUU: Penicilina VK 500 mgrs. cada 8 horas.

- Pacientes alérgicos a Penicilina: Levofloxacino 500 mgrs. cada 24 horas, durante 15 días. Alternativa: Azitromicina.

5. Administrar anti-inflamatorios no esteroideos (AINES) por vía oral.

6. Control evolutivo a los 15 días:

- Menor tamaño de exposición, desaparición o mejoría del dolor, desaparición de los signos flogóticos: pasar a tratamiento de estadio 1.

- Persistencia o agravamiento de la sintomatología: Mantener la misma pauta de tratamiento durante otros 15 días. Solicitar estudio complementario: TC (aunque se disponga de estudio previo)

7. Control evolutivo al mes:

- Desaparición del dolor, desaparición de los signos flogóticos: pasar a tratamiento de estadio 1. Promover, si la situación clínica lo requiere, la reincorporación del tratamiento con el aminobisfosfonato. Aplicar rigurosamente las normas de prevención.

- Persistencia o agravamiento de la sintomatología: valorar la necesidad del tratamiento recomendado para el estadio 3.

Estadio 3: exposición de hueso necrótico, en pacientes con dolor, signos de infección y evidencia clínica o radiográfica de secuestro óseo u otra complicación (tal como fracturas).

1. Recomendar, si fuera posible, la suspensión del aminobisfosfonato por parte del especialista que lo prescribió.

2. Administrar antibioterapia oral y enjuagues con clorhexidina según la pauta recogida en el estadio 2 .
4. 15-day follow-up:

Treatment of established osteonecrosis of the jaw (Fig. 5)

Stage 1: asymptomatic exposure of necrotic bone without signs of infection

1. Measurement of the dimensions of the exposed jawbone, in millimeters.

2.Discuss with the prescribing specialist the possible suspension of aminobisphosphonate use.

3. Prescribe rinsing with $0.12 \%$ or $0.2 \%$ clorhexidine mouthwash every 12 hours for 15 days.

- Exposed jawbone remains the same size or is smaller than at the time of diagnosis: continue the same regimen for another 15 days.

- The size of the exposed jawbone is larger or pain or signs of infection are present: apply stage 2 treatment.

5. One-month follow-up:

- The exposed jawbone lesion has improved or resolved: advise the attending specialist that aminobisphosphonate use may be resumed if the patient's clinical situation requires it. Apply strict prophylactic measures.

- The size of the exposed jawbone is larger or pain or signs of infection are present: apply stage 2 treatment.

Stage 2: exposed necrotic jawbone in patients with pain and signs of infection. Patients with a painful maxillary process not attributable to another cause and with radiologic signs of osteonecrosis may be included in this category. Point 1 of the following recommendations is not applicable to such cases (Fig. 6).

1. Measurement of the dimensions of the exposed jawbone, in millimeters.

2. Discuss with the prescribing specialist, if possible, the suspension of aminobisphosphonate use.

3. Prescribe rinsing with $0.12 \%$ or $0.2 \%$ clorhexidine mouthwash every 12 hours for 15 days.

4. Empirical administration of oral antibiotics (until microorganism culture and antibiotic susceptibility results become available):

- First indication: Amoxicillin/clavulanic acid 2000/125 mg every 12 hours, for 15 days. U.S. protocols: Penicillin VK 500 mg every 8 hours.

- Patients allergic to penicillin: Levofloxacin 500 mg every 24 hours, for 15 days. Alternatively: Azithromycin.

5. Administer oral nonsteroid anti-inflammatory drugs (NSAIDS).

6. 15-day follow-up:

- The size of the exposed jawbone is smaller, pain has disappeared or is diminished, and signs of inflamma- 
3. Bajo anestesia local, si fuera posible, eliminar el secuestro óseo incluyendo, si precisara, la exodoncia de los dientes involucrados, irrigación del lecho quirúrgico con clorhexidina 0,12\% y cierre del defecto con material reabsorbible.

4. Control evolutivo a los 15 días:

- Evolución favorable: suspender la antibioterapia oral y los antiinflamatorios. Mantener los enjuagues con el colutorio. Aplicar rigurosamente las normas de prevención sobre los dientes remanentes. Control a los 15 días.

- Evolución desfavorable (incremento en la exposición, dolor intenso, signos de infección): Mantener antibioterapia, enjuages y anti-inflamatorios durante 15 días.

5. Control evolutivo al mes:

- Evolución favorable: Promover, si la situación clínica lo requiere, la reincorporación del tratamiento con el aminobisfosfonato. Aplicar rigurosamente las normas de prevención sobre dientes remanentes.

- Evolución desfavorable: Programar nueva cirugía, igualmente conservadora bajo anestesia local.

- En circunstancias graves con fracaso de todas las medidas previas pueden plantearse situaciones complejas en las que puede proponerse cirugía alternativa, siempre lo mas conservadora posible:

- Fractura patológica: legrado tejido óseo necrótico y placa de reconstrucción (evitar injertos)

- ON hasta borde inferior: resección en bloque y placa de reconstrucción (evitar injertos)

- Fístula extraoral: desbridamiento eliminando áreas de ON que produzcan irritación mucosa. Medidas médicas descritas.

\section{Bibliografía}

1. American Dental Association Council on Scientific Affairs. Expert panel recommendations: dental management of patients receiving oral bisphosphonate therapy. I Am Dental Assoc 2006;137:1144-50.

2. American Association of Oral and Maxillofacial Surgeons. Advisory Task Force on Bisphosphonate-Related Ostenonecrosis of the Jaws, American Association of Oral and Maxillofacial Surgeons position paper on bisphosphonate-related osteonecrosis of the jaws. J Oral Maxillofac Surg 2007;65:369-76.

3. Bagán JV, Murillo J, Jiménez Y, Poveda R, Milian MA, Sanchos JM, y cols. Avascular jaw osteonecrosis in association with cancer chemoterapy: series of 10 cases. J Oral Pathol Med 2005;34:120-3.

4. Bagán JV, Jiménez Y, Murillo J, Hernández S, Poveda R, Sanchís JM, y cols. Jaw osteonecrosis associated with bisphosphonates: multiple exposed areas and its relationship to teeth extractions. Study of 20 cases. Oral Oncol 2006;42:327-9.

5. Barrientos FJ, Peral B, de la Peña G, Sánchez LA, García JM, Serrat A, y cols. Osteonecrosis de los maxilares inducida por bisfosfonatos: prevención y actitud terapeútica. Rev Esp Cir Oral Maxilofac 2007;29:295-308.

6. Black DM, Delmas PD, Eastell R, Reid IR, Boonen S, Cauley JA, y cols. Once-yearly zoledronic acid for treatment of postmenopausal osteoporosis. N Engl / Med 2007;356:1809-22.

7. Boonyapakorn T, Schirmer I, Reichart PA, Sturm I, Massenkeil G. Bisphosphonate-induced osteonecrosis of the jaws: prospective study of 80 patients with tion and infection have disappeared: pass to stage 1 treatment.

- Symptoms persist or are worse: Continue the same therapeutic regimen for another 15 days. Order complementary studies: CT (regardless of whether or not a previous CT scan is available)

7. One-month follow-up:

- Pain has disappeared and signs of inflammation and infection have disappeared: pass to stage 1 treatment. Recommend, if the clinical situation requires it, resumption of aminobisphosphonate treatment. Apply strict prophylactic measures.

- Symptoms persist or are worse: Assess the need for stage 3 therapy.

Stage 3: exposure of necrotic jawbone in patients with pain, signs of infection, and clinical or radiographic evidence of sequestration or other complications (such as fracture).

1. Discuss with the prescribing specialist, if possible, the suspension of aminobisphosphonate use.

2. Administer oral antibiotics and clorhexidine mouthwash according to stage 2 guidelines.

3. Eliminate sequestered bone under local anesthesia, if possible. If necessary, remove the teeth involved, irrigate the surgical bed with $0.12 \%$ clorhexidine, and close the defect with resorbable material.

4. 15-day follow-up:

- Favorable evolution: suspend oral antibiotics and antiinflammatory drugs. Continue rinsing with mouthwash. Apply strict prophylactic measures for the remaining teeth. 15-day follow-up:

- Unfavorable evolution (increased jawbone exposure, intense pain, signs of infection): Continue antibiotics, mouthwash, and anti-inflammatory drugs for 15 days.

5. One-month follow-up:

- Favorable evolution: Recommend, if the clinical situation requires, resumption of aminobisphosphonate treatment. Apply strict prophylactic measures for the remaining teeth.

- Unfavorable evolution: Schedule surgery, which should consist of a conservative intervention under local anesthesia.

- Under serious circumstances in which all of the previous measures have failed, complex situations may arise in which alternative surgery may be considered. Nonetheless, any surgical interventions should be as conservative as possible:

- Pathological fracture: debridement of necrotic bone tissue and insertion of a reconstruction plate (avoid grafts).

- Osteonecrosis extending to the lower edge: block resection and insertion of a reconstruction plate (avoid grafts).

- Extraoral fistula: debridement and elimination of areas of osteonecrosis that produce mucosal irritation. The medical measures described above. 
multiple myeloma and other malignancies. Oral Oncol 2008 doi:10.1016/j.oraloncology 2007.11.012.

8. Bilezikian JP. Osteonecrosis of the jaw--do bisphosphonates pose a risk? N Engl J Med 2006;355:2278-81.

9. Dannemann C, Grätz KW, Zwahlen R. Clinical experiences with bisphosphonate-induced osteochemonecrosis of the jaws. Swiss Med Wkly 2006;136:504-9.

10. Del Castillo JL, García JA, Arroyo S, Galdeano M, Calderón J. Osteonecrosis de los maxilares asociada al empleo de bifosfonatos. Rev Esp Cir Oral Maxilofac 2007; 29:295-308.

11. Dello Russo NM, Jeffcoat MK, Marx RE, Fugazzotto P. Osteonecrosis in the jaws of patients who are using oral biphosphonates to treat osteoporosis. Int J Oral Maxillofac Implants 2007;22:146-53.

12. Grant BT, Amenedo C, Freeman K, Kraut RA. Outcomes of placing dental implants in patients taking oral bisphosphonates: a review of 115 cases. J Oral Maxillofac Sur 2008;66:223-30.

13. Gutta R, Louis PJ. Bisphosphonates and osteonecrosis of the jaws: science and rationale. Oral Surg Oral Med Oral Pathol Oral Radiol Endod 2007; 104:186-93.

14. Hewitt C, Camile SF. Bisphosphonate-related osteonecrosis of the jaws: a comprehensive review. J Oral Pathol Med 2007;36:319-28.

15. Infante P, Cabezas A, Pérez JL, Palomino J, Gutiérrez JL. Bisphosphonate-related osteonecrosis of the jaw in patients with multiple myeloma. Med Oral Patol Oral Cir Bucal 2008;13:52-7.

16. Jiménez Y, Bagan JV. Los Bisfosfonatos, nueva causa de osteonecrosis maxilar por fármacos: Situación actual. Med Oral Patol Oral Cir Bucal 2005; 10:88-91.

17. Kyle RA, Yee GC, Somerfield MR, Flynn PJ, Halabi S, Jagannath S, Orlowski RZ. y cols. American Society of Clinical Oncology 2007. Clinical Practice Guideline Update on the role of Bisphosphonates in Multiple Myeloma. J Clin Oncol 2007; 25:2464-72.

18. Lam DK, Sándor GK, Holmes HI, Evans AW, Clokie CM. A review of bisphosphonate-associated osteonecrosis of the jaws and its management. J Can Dent Assoc 2007;73:417-22.

19. Leite AF, Figueiredo PT, Melo NS y cols. Bisphosphonate-associated osteonecrosis of the jaws. Report of a case and literature review. Oral Surg Oral Med Oral Pathol Oral Radiol Endod 2006;102:14-21.

20. Marx RE. Pamidronate (Aredia) and zolendronate (Zometa) induced avascular necrosis of the jaws: a growing epidemic. J Oral Maxillofac Surg 2003;61:1115-7.

21. Marx RE, Sawatari Y, Fortin M, Broumand V. Bisphosphonate-induced exposed bone (osteonecrosis/osteopetrosis) of the jaws: risk factors, recognition, prevention, and treatment. J Oral Maxillofac Surg 2005;63:1567-75.

22. Marx RE Joseph E. Cillo JE, Ulloa JJ. Oral bisphosphonate-induced osteonecrosis: Risk factors, prediction of risk using serum CTX testing, prevention, and treatment. J Oral Maxillofac Surg 2007;65:2397-410.

23. Mavrokokki T, Cheng A, Brien S, Goss A. Nature and frequency of bisphosphonate-associated osteonecrosis of the jaws in Australia. J Oral Maxillofac Surg 2007; 65:415-23.

24. Merigo E, Manfredi M, Meleti M y cols. Bone necrosis of the jaws associated with bisphosphonate treatment: a report of twenty-nine cases. Acta Biomed 2006;77:109-17.

25. Pastor-Zuazaga D, Garatea-Crelgo J, Martino-Gorbea R, Etayo-Pérez A, Sebastián-López C. Osteonecrosis maxilar y bisfosfonatos. Presentación de tres nuevos casos. Med Oral Patol Oral Cir Bucal 2006;11:57-60.

26. Ponte N, Estefanía R, Aguirre JM. Bisfosfonatos y patología oral I. Aspectos generales y preventivos. Med Oral Patol Oral Cir Bucal 2006;11:396400.

27. Rogers MJ, Benford HL, Coxon FP, Luckman SP, Monkkonen J, Frith JC. Cellular and molecular mechanism of action of bisphosphonates. Cancer 2000;88: 2961-78.

28. Ruggiero SL, Mehrotra B, Rosenberg TJ, Engroff SL. Osteonecrosis of the jaws associated with the use of bisphosphonates: a review of 63 cases. J Oral Maxillofac Surg 2004;62:527-34.

29. Ruggiero SL, Woo SB. Biophosphonate-related osteonecrosis of the jaws. Dent Clin North Am 2008;52:111-28.

30. Ruggiero SL, Fantasia J, Carlson E. Bisphosphonate-related osteonecrosis of the jaw: background and guidelines for diagnosis, staging and management. Oral Surg Oral Med Oral Pathol Oral Radiol Endod 2006;102:433-41.

31. Sarin J, Derossi SS, Akintoye SO. Updates on bisphosphonates and potential pathobiology of bisphosphonate-induced jaw osteonecrosis. Oral Dis 2008;14:277-85.

32. Shenker NG, Jawad ASM. Bisphosphonates and osteonecrosis of the jaw. Rheumatology 2007;46:1049-51.

33. Van den Wyngaert T, Huizing MT, Vermorken JB. Bisphosphonates and osteonecrosis of the jaw: cause and effect or a post hoc fallacy? Annals of Oncology 2006;17:1197-1204.

34. Wang HL, Weber D, McCauley LK. Effect of long-term oral bisphosphonates on implant wound healing: literature review and a case report. J Periodontol 2007;78:373-6.

35. Woo SB, Hellstein JW, Kalmar JR. Systematic review: Bisphosphonates and Osteonecrosis of the Jaws. Ann Intern Med 2006;144:753-761. 